九州大学学術情報リポジトリ

Kyushu University Institutional Repository

\title{
Respiration Rate of Thirteen Kinds of Japanese Fresh Vegetables
}

\section{Murata, Satoshi}

Laboratory of Agricultural Process Engineering, Faculty of Agriculture, Kyushu University

Miyauchi, Kiyoshi

Laboratory of Agricultural Process Engineering, Faculty of Agriculture, Kyushu University

Wang, Yanyao

Laboratory of Agricultural Process Engineering, Faculty of Agriculture, Kyushu University

https://doi.org/10.5109/24011

出版情報：九州大学大学院農学研究院紀要. 37 (2)，pp. 197-207，1992-12. Kyushu University バージョン：

権利関係 : 
J. Fac. Agr., Kyushu Univ., 37 (2), 197-207 (1992)

\title{
R espiration $R$ ate of Thirteen $K$ inds of J apanese Fresh Vegetables
}

\author{
Satoshi M urata, $\mathrm{K}$ iyoshi M iyauchi and $\mathrm{Y}$ anyao $\mathrm{W}$ ang \\ Laboratory of Agricultural Process Engineering, Faculty of Agriculture, \\ Kyushu University 46 -05, Fukuoka 812, Japan
}

(Received July 31, 1992)

\begin{abstract}
The respiration rate of fresh vegetables has the fundamental significance in storage, but there is few data available on respiration under wide range of temperature. In this study, the relationship between respiration rate and temperature of thirteen kinds of Japanese vegetables were measured by modern precise ventilatory method. Because of respiration being a result of chemical reaction, the relationships between respiration rate and temperature were fitted to Arrhenius' equation and Gore's equation (Modified Arrhenius' equation). The heat of respiration in $\mathrm{kJ}$ per ton per day was obtained multiplying the respiration rate of milligrams of $\mathrm{CO}_{2}$ per kilogram per hour by a factor of 10.61 . The heats of respiration were all a little higher than the conventional values.
\end{abstract}

\section{INTRODUCTION}

The quality maintenance of fresh vegetables has the significance in storage. In fresh vegetables the consumption reserves of living cells for respiration to produce energy leads to decline the quality of the product. In addition, the generation of heat accompanying the respiration process affects the storage conditions. So it is very important to investigate the characteristics of respiration under various conditions, for quality maintenance of fresh vegetables in storages. Though there are a lot of data on respiration under various local conditions (Honda and Ishiguro, 1967), the respiration data under wide range of temperature is not available presently (specially of Japanese vegetables). In this study the relationship between respiration rate and temperature of wide range for thirteen kinds of Japanese vegetables were measured by modern precise ventilatory method.

Respiration is a typical biochemical reaction in plants. In this process plants get energy' by sugar, acid and fat decomposition. The temperature dependence of biochemical reaction rate is ruled by the Arrhenius' equation just like other general chemical reactions (Sutcliffe, 1981). Also Gore's equation is celebrated as a equation of relationship between respiration rate and temperature. In this paper, measured results were analyzed by both equations and calculated the temperature coefficients. It is expected that the data of this study will contribute to the fundamental data for designing a rational storage equipment, estimation of quality of vegetables in storage and for storage physiology studies.

\section{APPARATUS AND PROCEDURE}

\section{M easurement apparatus}

The apparatus used for measurement is shown in Fig. 1. Samples were placed in a 


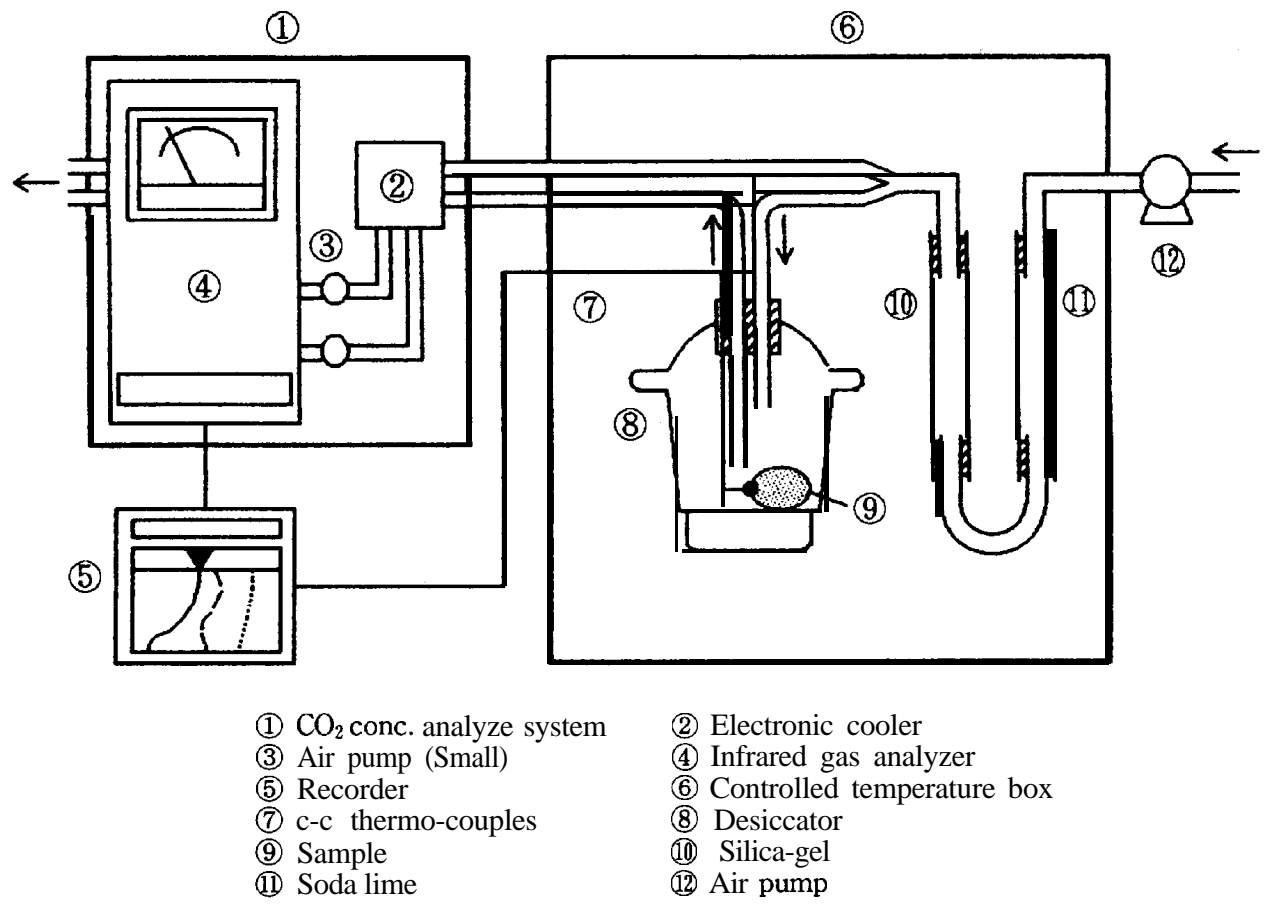

Fig. 1. Schematic diagram of measurement apparatus.

desiccator in the controlled temperature box.

Fresh air was pumped to the controlled temperature box through a plastic tube and then the air was passed over silica gel to dehumidified the flow. In the next step flow of air was passed over the soda lime to reduce the $\mathrm{CO}_{2}$ content. Then the flow was separated into the sample desiccator and bypass. Then the air in these two pathways were separately dehumidified by using electronic cooler and the dirt and dust were removed by passing through a membrane filter, then passed through a flow meter via a needle valve and an air-pump. Then these two air flows were fed to the infrared gas analyzer with a constant rate (Shimadzu Co, 1988a).

This equipment has two cells and detects the concentration difference of $\mathrm{CO}_{2}$ in these two air flows (Shimadzu Co, 1988b).

The temperature of the surface of the sample, and the dry and wet bulb temperatures of the desiccator were measured by using c-c thermocouples.

\section{Respiration rate}

Thirteen kinds of Japanese vegetables were used in this study (Table 1). For the temperature range of $0{ }^{\circ} \mathrm{C}$ to $25^{\circ} \mathrm{C}$, the difference of $\mathrm{CO}_{2}$ concentrations in ppm were measured. Respiration rates of milligrams of $\mathrm{CO}_{2}$ per kilogram per hour were calculated by using the following equation. 
Table 1. Materials.

\begin{tabular}{|c|c|c|c|}
\hline Materials & Variety & Producing area & $\begin{array}{l}\text { Date of } \\
\text { hervest }\end{array}$ \\
\hline Spinach & Atlas & Kanetake Nishi-ku, Fukuoka & '91.11.24 \\
\hline Coronarium & Chuba & Sue Kasuya, Fukuoka & 91.12 .25 \\
\hline Chinese cabbage & Sin Risoh & Hita, Ohita & '92. 1.04 \\
\hline Lettuce (Head) & Top Mark & Tachiarai Mii, Fukuoka & '92. 1.15 \\
\hline Asparagus & Welcome & Saga, Saga Pref & '92. 1.22 \\
\hline Onion & Momiji II & Marugame, Kagawa & 91.6. \\
\hline Carrot (topped) & Kuroda Gosun & Isahaya, Nagasaki & '91.12.16 \\
\hline Turnip (topped) & Taibyohikari & Kanetake Nishi-ku, Fukuoka & 91.12 .15 \\
\hline Potato & $\begin{array}{l}\text { May Queen } \\
\text { Deiima }\end{array}$ & $\begin{array}{l}\text { Memuro Kawanishi, Hokkaido } \\
\text { Sue Kasuya, Fukuoka }\end{array}$ & $\begin{array}{l}91.9 . \\
91.12 .14\end{array}$ \\
\hline Sweet potato & Miyazaki Aka & Ohtsuka Kushima, Miyazaki & 91.10 \\
\hline Taro & Hasuba Imo & Nishihara Aso, Kumamoto & ‘91.11. \\
\hline Citrus Unshu & Unsyu Okute & Yamakawa Yamato, Fukuoka & ‘91.12. \\
\hline Persimmon & Fuyu & Haki Asakura, Fukuoka & ‘91.11.30 \\
\hline
\end{tabular}

$$
\begin{aligned}
\mathrm{R} & =10^{3} \mathrm{M} \cdot \frac{60 \cdot \mathrm{q} \cdot \mathrm{x} \cdot 10^{-6}}{22.40 \cdot \frac{\mathrm{T}}{273.15} \cdot \mathrm{W}} \\
& =0.7317 \cdot \frac{\mathrm{M} \cdot \mathrm{q}}{\mathrm{T} \cdot \mathrm{W}} \cdot \mathrm{x} \ldots \ldots \ldots(1)
\end{aligned}
$$

where $\mathrm{R}$ : respiration rate $\left(\mathrm{CO}_{2} \mathrm{mg} / \mathrm{kg} / \mathrm{hr}\right)$

$\mathrm{M}$ : molecular weight of $\mathrm{CO}_{2}(=44)$

$\mathrm{q}:$ flow rate $(1 / \mathrm{min})$

$\mathrm{x}$ : measured difference of $\mathrm{CO}_{2}$ concentration (ppm)

$\mathrm{T}$ : surface temperature of sample $(\mathrm{K})$

$\mathrm{W}$ : weight of sample $(\mathrm{kg})$

\section{RESULTS AND DISCUSSION}

\section{Temperature dependency equation of respiration}

Arrhenius' equation and Gore's equation were used as equation of temperature dependency of respiration rate. Arrhenius' equation is used as equation of chemical reaction rate (Sutcliffe, 1981).

$$
\mathrm{R}=\mathrm{R}_{\mathrm{a}} \bullet \exp (-\alpha / \mathrm{T}) \cdots \cdots \cdots \cdots(2)
$$

where $\mathrm{R}$ : respiration rate $\left(\mathrm{CO}_{2} \mathrm{mg} / \mathrm{kg} / \mathrm{hr}\right)$

$\mathrm{R}_{\mathrm{a}}$ : coefficient

$\alpha$ : temperature coefficient

$\mathrm{T}$ : temperature $(\mathrm{K})$

Gore's equation is celebrated as a equation of temperature dependency, of 
respiration rate of fresh vegetables (Ogata, 1977), which is derived from Arrhenius' equation as approximation.

$$
\mathrm{R}=\mathrm{R}_{0} \cdot \exp (\beta \mathrm{t})
$$

where $\mathrm{R}$ : respiration rate $\left(\mathrm{CO}_{2} \mathrm{mg} / \mathrm{kg} / \mathrm{hr}\right)$

$\mathrm{R}_{0}$ : value of $\mathrm{R}$ at $0^{\circ} \mathrm{C}$

$\beta$ : temperature coefficient

$\mathrm{t}$ : temperature $\left({ }^{\circ} \mathrm{C}\right)$

Using these two equations, temperature coefficients were determined by the least square method. Temperature dependency of respiration rate for Asparagus by Arrhenius' equation and by Gore's equation are shown in Fig. 2 and 3. The obtained respiration characteristics data of Asparagus was well fitted to these equations. It is preferred to select either of the above equations for the purpose in practical requirements.

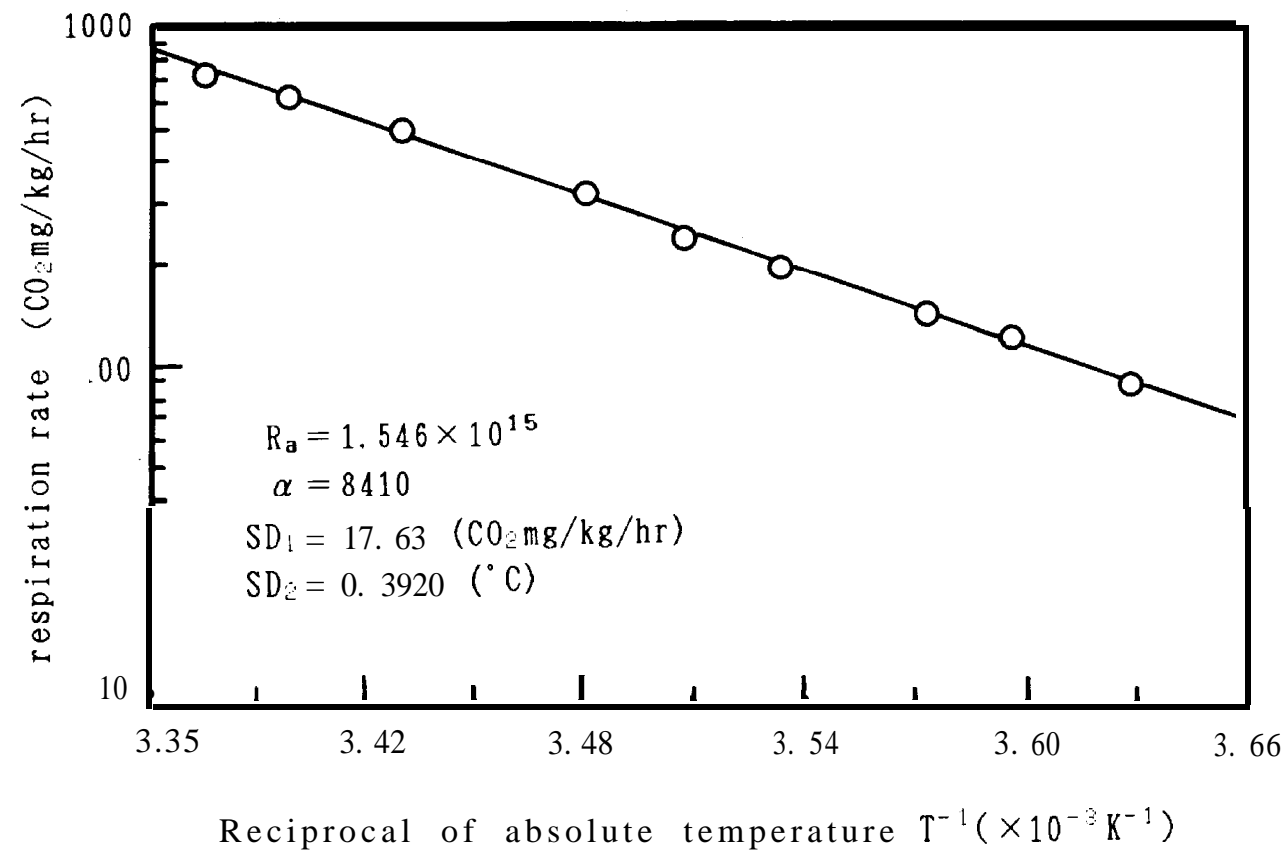

Fig. 2. Temperature dependency of respiration rate for asparagus (Eq. Arrhenius). 


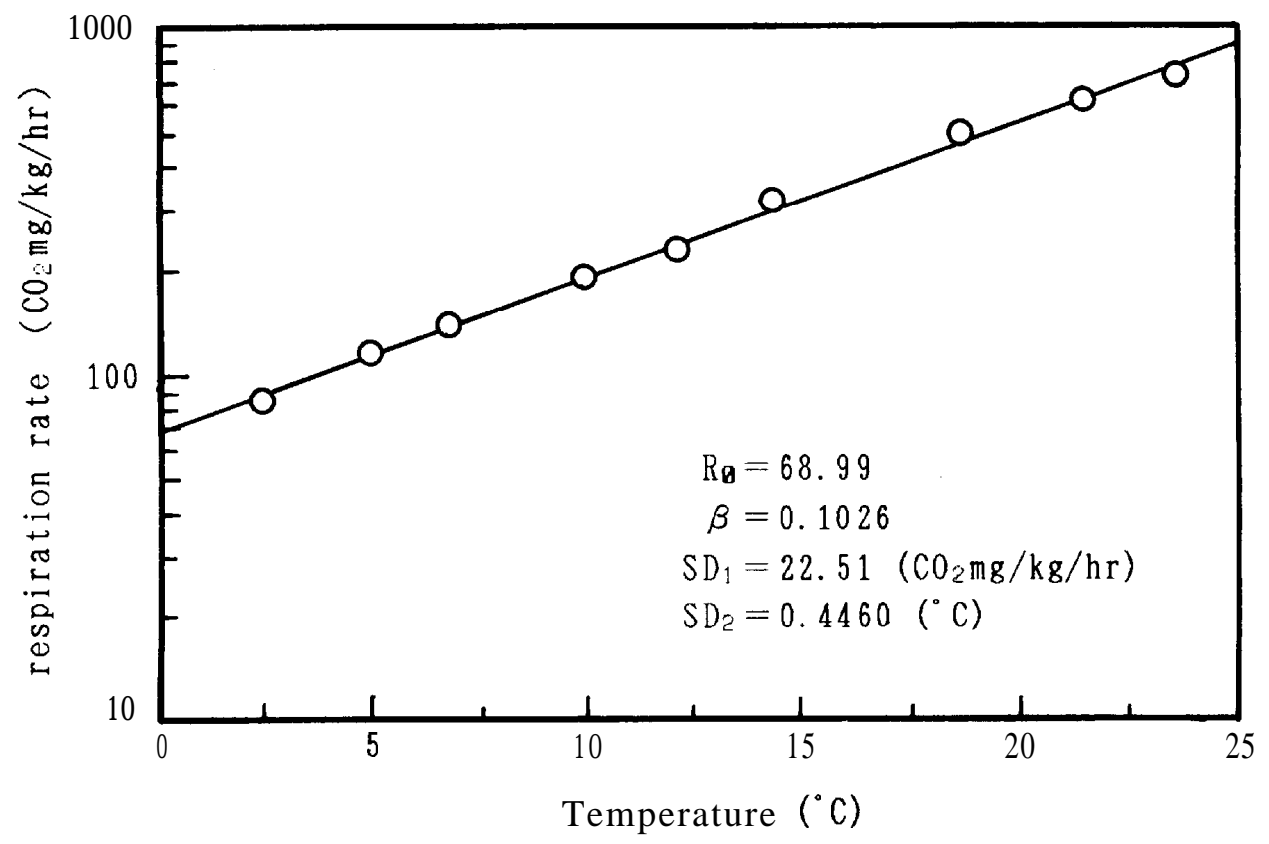

Fig. 3. Temperature dependency of respiration rate for asparagus ( Eq. Gore).

\section{Temperature coefficient}

Calculated temperature coefficients are shown in Table 2 . Results showed that the

Table 2. Temperature coefficient.

\begin{tabular}{c|c|c|c|c|c|c|c|c}
\hline \multirow{2}{*}{ Materials } & \multicolumn{2}{|c}{$\mathrm{R}=\mathrm{R}_{\mathrm{a}} \bullet \exp (-\alpha / \mathrm{T})\left(\mathrm{CO}_{2} \mathrm{mg} / \mathrm{kg} / \mathrm{hr}\right)$} & \multicolumn{3}{c}{$\mathrm{R}=\mathrm{R}_{\mathbf{0}} \cdot \exp (\beta \mathrm{t})\left(\mathrm{CO}_{2} \mathrm{mg} / \mathrm{kg} / \mathrm{hr}\right)$} \\
\cline { 2 - 8 } & $\mathrm{Ra}$ & $\alpha$ & $\mathrm{SD}_{1}$ & $\mathrm{SD}_{2}$ & $\mathrm{R}_{0}$ & $\beta$ & $\mathrm{SD}_{1}$ & $\mathrm{SD}_{2}$ \\
\hline Spinach & $2.144 \times 10^{14}$ & 8006 & 11.50 & 0.5784 & 41.83 & 0.09808 & 13.22 & 0.6643 \\
Coronarium & $9.355 \times 10^{15}$ & 8962 & 15.20 & 0.4033 & 55.74 & 0.1092 & 20.26 & 0.5205 \\
Chinese cabbage & $3.836 \times 10^{6}$ & 3418 & 1.366 & 1.147 & 14.41 & 0.04175 & 1.270 & 1.0498 \\
Lettuce (Head) & $1.893 \times 10^{5}$ & 2282 & 1.168 & 0.6451 & 45.08 & 0.02795 & 1.315 & 0.7246 \\
Asparagus & $1.546 \times 10^{15}$ & 8410 & 17.63 & 0.3920 & 68.99 & 0.1026 & 22.51 & 0.4460 \\
Onion & $1.327 \times 10^{6}$ & 3166 & 0.7701 & 0.8939 & 12.56 & 0.03844 & 0.8247 & 0.9608 \\
Carrots & $2.284 \times 10^{9}$ & 4883 & 4.732 & 0.6648 & 40.47 & 0.05953 & 5.356 & 0.7411 \\
Turnip & $8.732 \times 10^{12}$ & 7138 & 7.316 & 0.7547 & 33.24 & 0.06951 & 7.345 & 1.044 \\
Potato (Dejima) & $2.224 \times 10^{8}$ & 4496 & 1.688 & 1.033 & 16.11 & 0.05569 & 1.760 & 1.091 \\
(May Queen) & $1.194 \times 104$ & 2104 & 0.2289 & 1.2219 & 5.47 & 0.02569 & 0.2391 & 1.309 \\
Sweet potato & $2.404 \times 10^{10}$ & 5833 & 2.039 & 0.8040 & 13.26 & 0.07122 & 2.281 & 0.9109 \\
Taro & $1.123 \times 10^{10}$ & 5794 & 1.223 & 0.8514 & 7.07 & 0.07142 & 1.296 & 0.8482 \\
Citrus Unshu & $6.230 \times 10^{12}$ & 7401 & 4.898 & 1.094 & 11.23 & 0.08976 & 5.273 & 1.178 \\
Persimmon & $5.733 \times 10^{10}$ & 6214 & 0.7537 & 0.4212 & 7.75 & 0.07705 & 0.8925 & 0.4912 \\
\hline
\end{tabular}


vegetable which has comparatively higher growth rate and less reservation period has comparatively higher respiration rate. The respiration rate $\left(\mathrm{R}_{0}\right)$ of leafy vegetables (food synthesizing organ) were comparatively higher than potatoes (the stored organ of the plants). The respiration rate of root vegetables and fruits were between them. Same as leafy vegetables, Asparagus, which has remarkably high stem growth, showed higher respiration rate.

For leafy vegetables, root vegetables, potatoes and fruits, temperature dependency of respiration rate by Arrhenius' equation is shown in Fig. 4, 5, 6 and 7. Spinach and

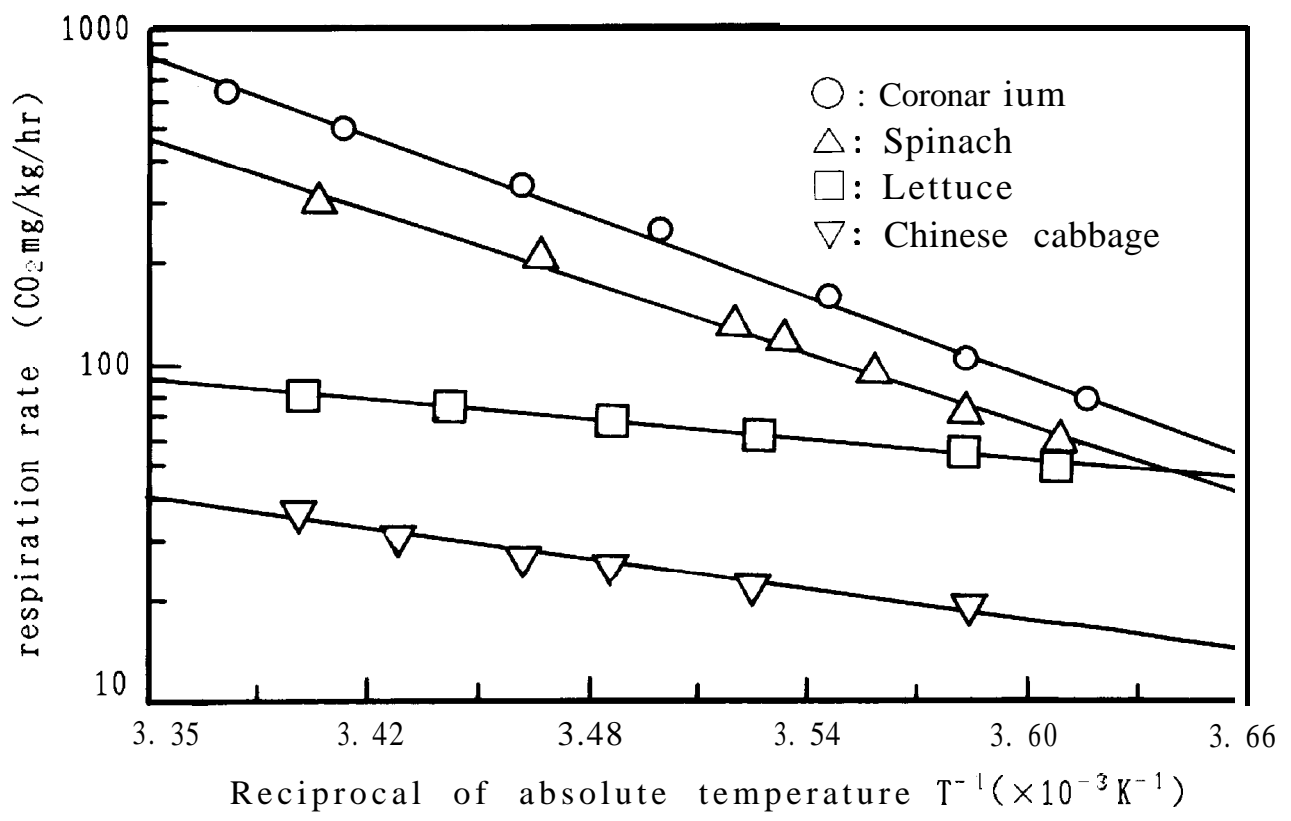

Fig. 4. Temperature dependency of respiration rate for leafy vegetables. 


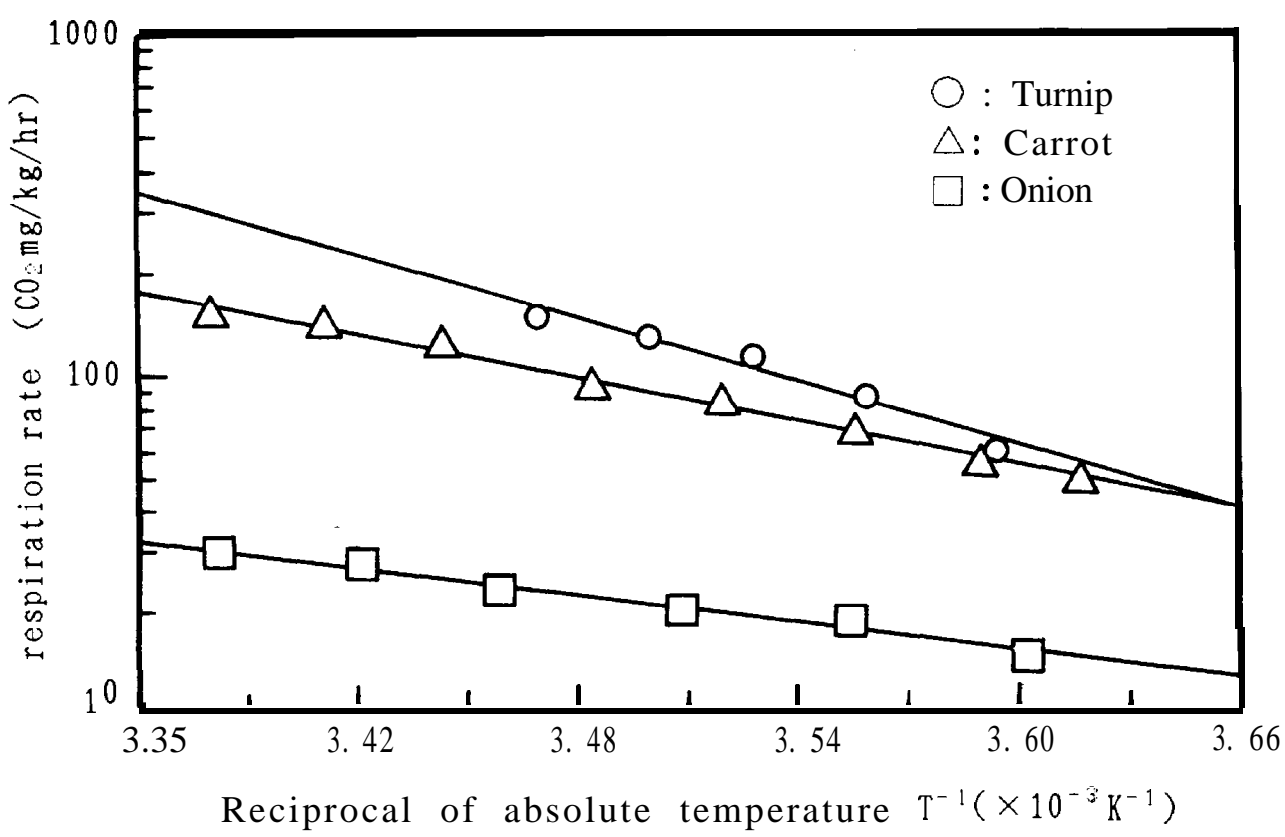

Fig. 5. Temperature dependency of respiration rate for root vegetables.

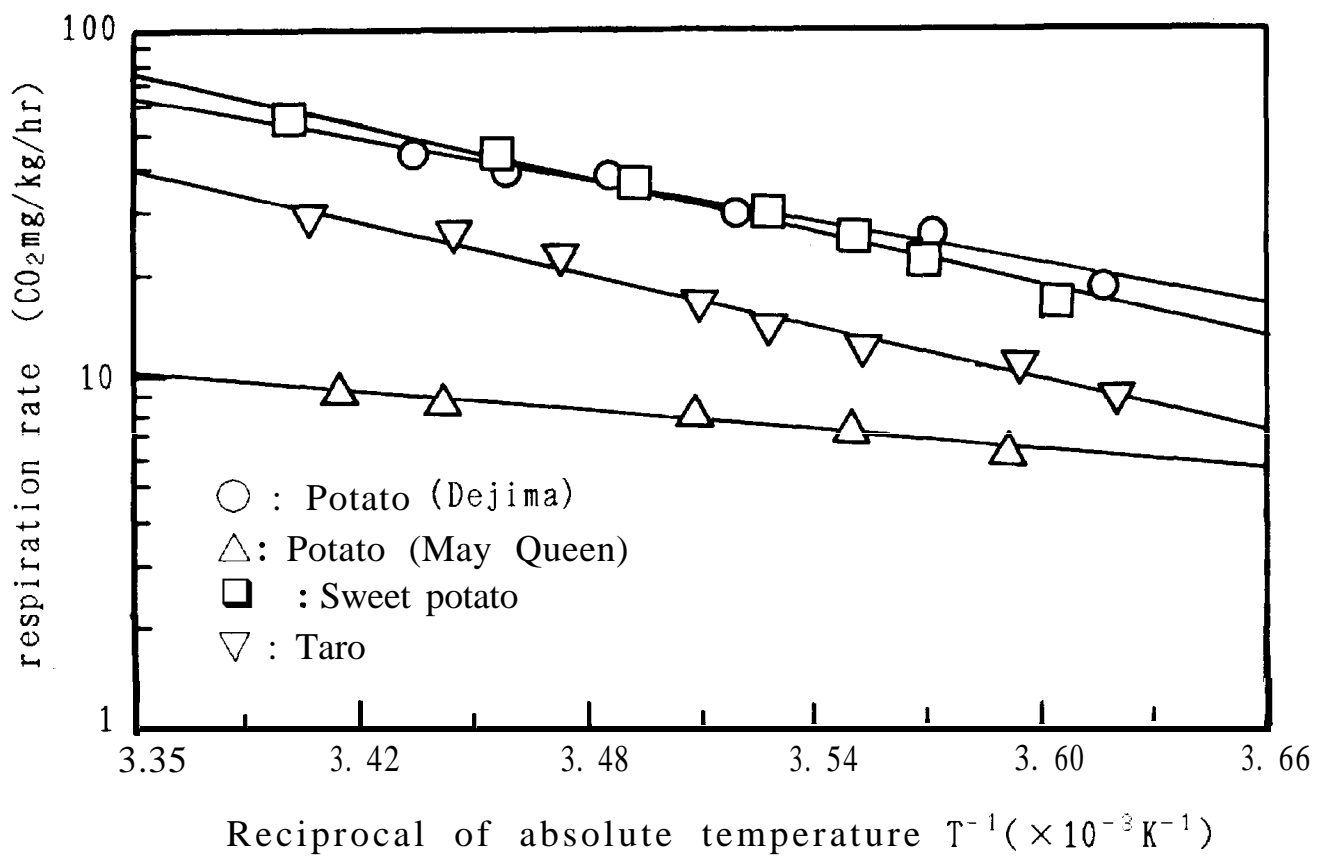

Fig. 6. Temperature dependency of respiration rate for potatoes. 


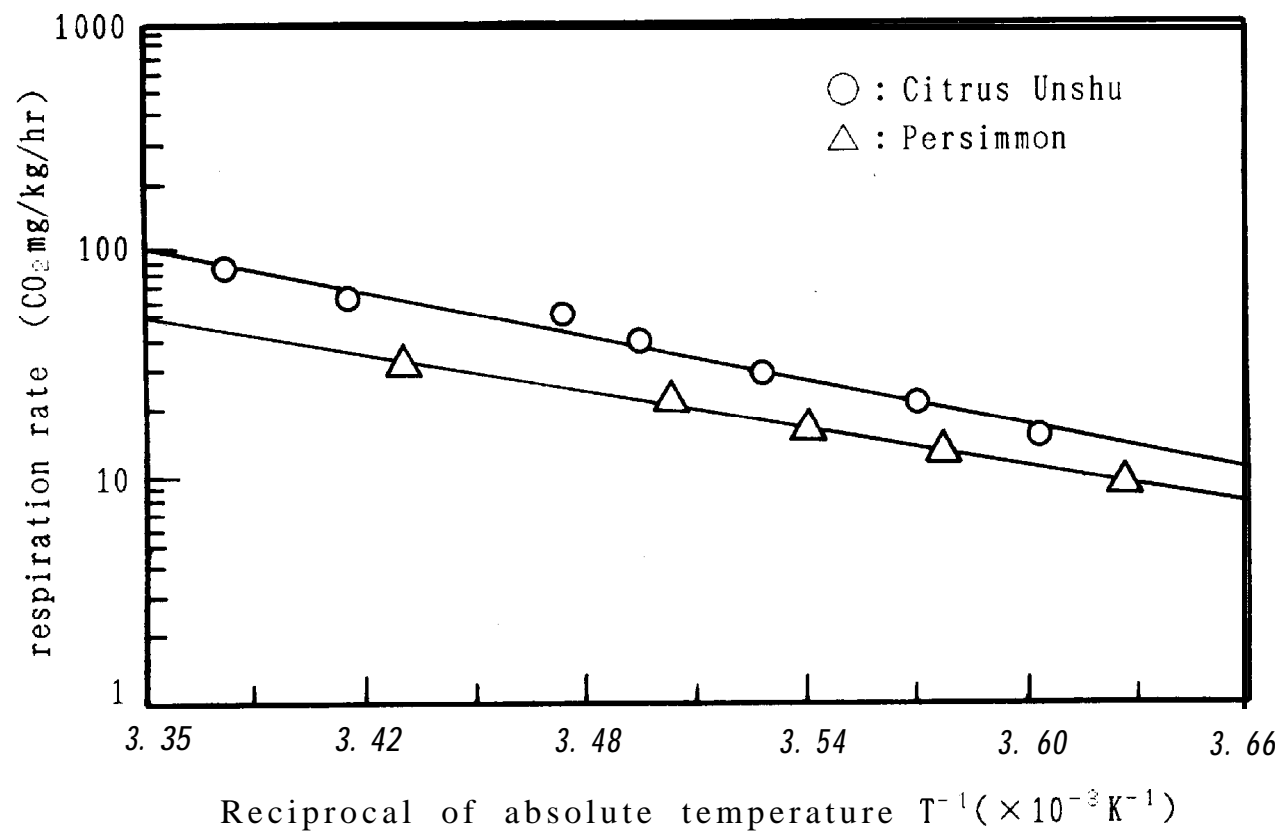

Fig. 7. Temperature dependency of respiration rate for fruits.

Coronarium having different leaf arrangement has higher respiration rates than that of the head type Lettuce and Chinese Cabbage. In root vegetables Turnip showed the same behavior as Carrot (topped) and higher respiration rate than that of Onion. Potato also showed the same behavior of temperature dependency, but lower respiration rate than the other vegetables. Specially potato variety of May-Queen showed the lowest respiration rate and it may be caused by cold storage before the experiment. In fruits, the temperature dependency characteristics of Citrus Unshu and Persimmon were look alike.

\section{Heat of respiration}

Heat of respiration is an important factor as a load in cold storage of fresh vegetables. But it is very difficult to measure directly and accurately. Conventional values of heat of respiration were generally estimated by respiration rate (Katoh, 1967. U.S. Dep. Agr., 1954). So in this study, heat of respiration was estimated by following equations based on oxidation of glucose.

$$
\begin{aligned}
& \mathrm{C}_{6} \mathrm{H}_{12} \mathrm{O}_{6}+6 \mathrm{O}_{2} \rightarrow 6 \mathrm{CO}_{2}+6 \mathrm{H}_{2} \mathrm{O}_{(\mathrm{l})}+2803 \mathrm{~kJ} \cdots \cdots \cdots \cdot(4) \\
& \mathrm{C}_{6} \mathrm{H}_{12} \mathrm{O}_{6}+6 \mathrm{O}_{2} \rightarrow 6 \mathrm{CO}_{2}+6 \mathrm{H}_{2} \mathrm{O}_{(\mathrm{g})}+2539 \mathrm{~kJ} \cdots \cdots \cdots \cdots(5)
\end{aligned}
$$

Calorific values of these chemical reactions were obtained by standard formation 
enthalpy of both sides of each of these equations 4 and 5 (J. Chem. Soc., 1984). The conversion coefficient per $\mathrm{CO}_{2}-\lg$ was 10.61 (eq.4).

$$
2803 /(6 \times 44)=10.61(\mathrm{k} \mathrm{J}) \cdots \cdots \cdots \cdots(6)
$$

The heat of respiration $\left(Q_{R}\right)$ in $\mathrm{kJ}$ per ton per day was obtained by multiplying the respiration rate of milligrams of $\mathrm{CO}_{2}$ per kilogram per hour with the factor of 10.61 .

$$
\mathrm{Q}_{\mathrm{R}}=10.61 \times \mathrm{R} \times 24 \ldots \ldots \ldots \ldots \ldots(7)
$$

Temperature and the correspondent calculated values of heat of respiration are shown in Table 3 . The values of heat of respiration were all a little higher than the

\begin{tabular}{|c|c|c|c|c|c|c|}
\hline \multirow{2}{*}{ Materials } & \multicolumn{6}{|c|}{ Heat of respiration at various temperature $(\mathrm{kJ} /$ ton/day) } \\
\hline & $0^{\circ} \mathrm{C}$ & $5^{\circ} \mathrm{C}$ & $10^{\circ} \mathrm{C}$ & $15^{\circ} \mathrm{C}$ & $20^{\circ} \mathrm{C}$ & $25^{\circ} \mathrm{C}$ \\
\hline Spinach & $\begin{array}{c}10170 \\
(4430 \sim 5170)\end{array}$ & $\begin{array}{c}17230 \\
(8020 \sim 13400\end{array}$ & 28640 & $\begin{array}{c}46780 \\
(31130 \sim 51910)\end{array}$ & $\begin{array}{c}75140 \\
(39990 \sim 66680\end{array}$ & $\begin{array}{c}118790 \\
-\end{array}$ \\
\hline Coronarium & 13450 & 24250 & 42840 & 74190 & 126090 & 210540 \\
\hline $\begin{array}{l}\text { Chainese } \\
\text { cabbage }\end{array}$ & 3590 & 4500 & 5580 & 6890 & 8430 & 10250 \\
\hline $\begin{array}{l}\text { Lettuce } \\
\qquad \text { (Head) }\end{array}$ & $\begin{array}{c}11330 \\
(1370 \sim 3900)\end{array}$ & $\begin{array}{c}11160 \\
(3060-4640)\end{array}$ & 15220 & $\begin{array}{c}17500 \\
(7390 \sim 10450)\end{array}$ & $\begin{array}{c}20030 \\
(11820 \sim 13930)\end{array}$ & $\begin{array}{c}22830 \\
(16990 \sim 21210)\end{array}$ \\
\hline Asparagus & $\begin{array}{c}16760 \\
(6540 \sim 13930\end{array}$ & $\begin{array}{c}29150 \\
13720 \sim 24370\end{array}$ & $\begin{array}{c}49710 \\
-\end{array}$ & $\begin{array}{c}83230 \\
(26910 \sim 54340)\end{array}$ & $\begin{array}{c}136920 \\
(40410 \sim 62460)\end{array}$ & $\begin{array}{c}221520 \\
(86310 \sim 110470)\end{array}$ \\
\hline Carrot & $\begin{array}{c}10020 \\
(2220 \sim 4750)\end{array}$ & $\begin{array}{c}13810 \\
(2950 \sim 4750)\end{array}$ & 18830 & $\begin{array}{c}25400 \\
(6010 \sim 12450)\end{array}$ & $\begin{array}{c}33910 \\
(10660 \sim 22050)\end{array}$ & 44840 \\
\hline Onion & $\begin{array}{c}3130 \\
(1010 \sim 1680)\end{array}$ & $\begin{array}{c}3850 \\
(1340 \sim 2180)\end{array}$ & $\begin{array}{c}4710 \\
(1970 \sim 2930)\end{array}$ & $\begin{array}{c}5720 \\
(2720 \sim 3980)\end{array}$ & $\begin{array}{c}6900 \\
(3140 \sim 5020)\end{array}$ & $\begin{array}{c}8270 \\
-\end{array}$ \\
\hline Turnip & $\begin{array}{r}8250 \\
(2010)\end{array}$ & $\begin{array}{c}11970 \\
(2220 \sim 2320)\end{array}$ & 17130 & $\begin{array}{c}24210 \\
(4960 \sim 5590)\end{array}$ & $\begin{array}{c}33820 \\
(5590 \sim 5800)\end{array}$ & $\begin{array}{c}46720 \\
-\end{array}$ \\
\hline $\begin{array}{l}\text { Potato } \\
\quad \text { (Dejima) }\end{array}$ & 4020 & 5410 & 7200 & 9480 & 12370 & 16000 \\
\hline (May Queen) & $\begin{array}{c}1370 \\
(920 \sim 2260)\end{array}$ & $\begin{array}{c}1580 \\
(1050 \sim 1680)\end{array}$ & $\begin{array}{c}1800 \\
(1420 \sim 1880)\end{array}$ & $\begin{array}{c}2050 \\
(1680 \sim 3140)\end{array}$ & $\begin{array}{c}2320 \\
(2090 \sim 3770)\end{array}$ & 2620 \\
\hline Sweet Potato & 3260 & $\begin{array}{c}4780 \\
-\end{array}$ & $\begin{array}{c}6920 \\
-\end{array}$ & $\begin{array}{c}9900 \\
(4540 \sim 5590)\end{array}$ & 13980 & $\begin{array}{c}19510 \\
-\end{array}$ \\
\hline Taro & 1750 & 2570 & 3710 & 5290 & 7460 & 10390 \\
\hline Citrus Unshu & 2710 & 4420 & 7070 & 11120 & 17240 & 26320 \\
\hline Persimmon & 1920 & $\begin{array}{r}2900 \\
(1370)\end{array}$ & $\begin{array}{c}4300 \\
-\end{array}$ & $\begin{array}{c}6290 \\
(2740 \sim 3270)\end{array}$ & $\begin{array}{c}9090 \\
(4640 \sim 5590)\end{array}$ & $\begin{array}{c}12960 \\
(6750 \sim 9290)\end{array}$ \\
\hline
\end{tabular}

Table 3. Heat of respiration.

conventional values (Katoh, 1967. U.S. Dep. Agr., 1954) (parenthesized values under the each relevant entries in the Table 4). In each vegetable the values were about three times of the conventional values under $0^{\circ} \mathrm{C}$. The higher the temperature smaller the difference between the calculated value and the conventional. In the conventional method of closed system the accumulation of $\mathrm{CO}_{2}$ itself may retared the respiration rate and also affects on the measurement accuracy adversely, whilst in this study the difference of $\mathrm{CO}_{2}$ concentration was momentarily measured by modern precise 
ventilatory method with the help of infrared gas analyzer.

\section{The temperature coefficient $\left(Q_{10}\right)$}

Temperature coefficient $Q_{10}$ is an index for estimation of temperature effect in biological processors. $\mathrm{Q}_{10}$ is generally about 2 and becomes higher in lower temperatures. $\mathrm{Q}_{10}$ values of respiration rates were obtained by temperature coefficient determined by Arrhenius' equation. The results are shown in Table 4.

Table 4. Values of $Q_{10}$.

\begin{tabular}{c|c|c|c|c}
\hline \multirow{2}{*}{ Materials } & \multicolumn{3}{|c}{$\mathrm{Q}_{10}$} \\
\cline { 2 - 5 } & $0^{\circ} \mathrm{C} \sim 10^{\circ} \mathrm{C}$ & $5{ }^{\circ} \mathrm{C} \sim 15^{\circ} \mathrm{C}$ & $10^{\circ} \mathrm{C} \sim 20^{\circ} \mathrm{C}$ & $15^{\circ} \mathrm{C} \sim 25^{\circ} \mathrm{C}$ \\
\hline Spinach & 2.815 & 2.715 & 2.624 & 2.539 \\
Coronarium & 3.186 & 3.059 & 2.944 & 2.838 \\
Chinese cabbage & 1.556 & 1.532 & 1.510 & 1.489 \\
Lettuce (Head) & 1.343 & 1.329 & 1.317 & 1.304 \\
Asparagus & 2.966 & 2.856 & 2.754 & 2.661 \\
Onion & 1.506 & 1.484 & 1.464 & 1.446 \\
Carrots & 1.880 & 1.839 & 1.801 & 1.765 \\
Turnip & 2.517 & 2.437 & 2.363 & 2.295 \\
Potato (Dejima) & 1.788 & 1.752 & 1.719 & 1.688 \\
(May Queen) & 1.317 & 1.300 & 1.288 & 1.277 \\
Sweet potato & 2.126 & 2.070 & 2.019 & 1.972 \\
Taro & 2.115 & 2.060 & 2.010 & 1.963 \\
Citrus Unshu & 2.604 & 2.518 & 2.439 & 2.367 \\
Persimmon & 2.233 & 2.171 & 2.114 & 2.061 \\
\hline
\end{tabular}

The value of $\mathrm{Q}_{10}$ of all kinds of vegetables is nearly 2, and it is lower than the value of various vegetables under $0^{\circ} \mathrm{C}$ to $24^{\circ} \mathrm{C}$ measured by Platenius (Platenius, 1942). Calculated values have no difference at various temperatures, but they are indexes for investigation of respiration of vegetables.

\section{CONCLUSIONS}

The relationship between respiration rate and temperature of thirteen kinds of Japanese vegetables were measured, and the data of this study will contribute to the fundamental data for designing a rational storage equipment, estimation of quality of vegetables in storages and for storage physiology studies.

The results showed that ;

1) Measured results were fitted to Arrhenius' equation and Gore's equation of temperature dependency.

2) Rate of respiration increases in the order of leafy vegetables, root vegetables, fruits and potatoes.

3) The heats of respiration were all a little higher than the conventional values.

4) The values of $Q_{10}$ were nearly 2 . 
Because these kind of data is little available at the present the results of this study will be helpful not only for storage design but also physiology studies etc.

\section{ACKNOWLEDGEMENTS}

The materials used in this study were provided by Fukuoka prefectural horticultural cooperative association. Thanks for the assistance of Mr. T. Kohtake and Mr. K. Kinoshita. We also wish to thank Mr. K.S.P. Amaratunga for assistance with the English form of the manuscript.

\section{REFERENCES}

Honda, Y., Ishiguro, 0. 1967 Studies on the storage of fruits and vegetables. I . The effect of the composition of atmospheric gases on the respiration of fruits and vegetables during the storage. (part 1). J. Japan. Hort. Sci, 36(3): 101-1101

Japanese Chemical Society 1984 The Handbook of Chemistry, 3rd ed. fundamental volume II. Mruzen Publishing Inc., Tokyo, pp. 305-315

Katoh, S. 1967 The cold chain of fresh fruits and vegetables(17). Agriculture and Horticulture, 43(5): $139-142$

Ogata, K. 1977 The general remark for storage of fresh fruits and vegetables. Kenpakusha Publishing Inc., Tokyo, pp. 52-53

Plantenius, H. 1942 Plant Physiol, 17: 179-197

Shimadzu factory Co. 1988a The manual of high sensitive $\mathrm{CO}_{2}$ concentration analyze system for biological experiment (IRA-102). pp. 4

Shimadzu factory Co. 1988b The manual of infrared gas analyzer (URA-106). pp. 4-6

Sutcliffe, J. F. 1981 Plants and temperature. Transl, by Y. Satoh, Asakura Publishing Inč., Tokyo, pp. 25-26

United States Agricultural Research Service 1954 The Commercial Storage of Fruits, Vegetables and Florlist and Nursery Stocks. U.S. Dept. Agr., pp. 8-9 